\title{
Pre-Prosthetic Preparation in the Treatment with Fixed Prosthetic Constructions
}

\author{
Desislava Konstantinova, Anna Nenova-Nogalcheva
}

\begin{abstract}
The authors' aim was to determine the role of pre-prosthetic periodontal preparation in the life expectancy of dental bridges. Materials and methods: A retrograde screening study was performed on 58 patients with bridge restorations, subsequently divided into two groups: Group 1 involved patients who had undergone pre-prosthetic periodontal preparation and Group 2 where patients had not had any pre-prosthetic periodontal preparation. Inclusion criteria were subjective complaints, life span of the bridge, evaluated according to the three medico-biological criteria and according to the periodontal pocket depth. Changes were followed up in four successive examinations: after 1 week, 1 year, 2 years and 5 years. Results: The results pointed towards a significant correlation between participants' affiliation to a particular group (Group 1 or Group 2) and the progression of the periodontal pocket depth (P=0.20). $A$ linear correlation was established between the number of patients in Group 2 and any discrepancies in the preventive $(R=0.792, P$ $<0.01)$, functional $(R=0.742, P<0.01)$ and aesthetic criteria $(R=0.881, P<0.01)$. At the first control examination, Group 2 patients had subjective complaints which over time (after 3 years and 5 years) intensified. Such observations were not found among Group 1participants. Conclusion: The longevity of dental bridge prostheses is contingent on the state of the hard and soft tissue of the oral cavity. Pre-prosthetic periodontal preparation is essential in achieving long-term functionality, lack of subjective complaints and good aesthetics.
\end{abstract}

Keywords: pre-prosthetic preparation, fixed constructions

\section{Introduction}

Periodontitis is defined as inflammatory destructive lesions induced by infectious agents[1,2]. Shortly after fitting the prosthesis there is an early bacterial colonization and biofilm formation occurring in the prosthetic construction [3]. There are studies supporting that areas affected by periodontal infection may serve as a reservoir for pathogenic microorganisms that can pass from infected areas to healthy tissue, multiply and cause disease [4]. Hence, pre-prosthetic preparation is fundamental for the successful prosthetic treatment of the masticatory apparatus using fixed prosthetic devices [5, 6]. In modern dentistry, that can be easily achieved when an interdisciplinary approach is applied [7, $8]$.

\section{Aim}

To determine the role of pre-prosthetic periodontal preparation in the longevity of fixed dental constructions for the rehabilitation of the masticatory apparatus.

\section{Material and Methodology}

A retrograde screening study was performed on patients with bridge restorations, referred to specialized prosthetic and periodontal treatment by their general practitioners. The target of the study were 88 prosthetic devices (48 in the maxilla and 40 in the mandible), fixed onto 489 abutment teeth. (Table 1)
Table 1: Frequency distribution of abutment teeth

\begin{tabular}{|l|l|l|l|}
\hline Type of dental construction & $\begin{array}{l}\text { Maxillary } \\
\text { dental } \\
\text { bridges }\end{array}$ & $\begin{array}{l}\text { Mandibular } \\
\text { dental } \\
\text { bridges }\end{array}$ & $\begin{array}{l}\text { Total } \\
\text { number } \\
\text { of abutment } \\
\text { teeth }\end{array}$ \\
\hline $\begin{array}{l}\text { 3-unit dental bridge with 2 } \\
\text { abutment teeth }\end{array}$ & 3 & 10 & 26 \\
\hline $\begin{array}{l}\text { 4-unit dental bridge with 4 } \\
\text { abutment teeth }\end{array}$ & 5 & 10 & 45 \\
\hline $\begin{array}{l}\text { 5-unit dental bridge with 4 } \\
\text { abutment teeth }\end{array}$ & 10 & 8 & 72 \\
\hline $\begin{array}{l}\text { 7- or 8-unit dental bridge with 6 } \\
\text { abutment teeth }\end{array}$ & 14 & 7 & 136 \\
\hline $\begin{array}{l}\text { Cross-arch stabilizing bridge with } \\
10 \text { abutment teeth }\end{array}$ & 16 & 5 & 210 \\
\hline Total & 305 & 184 & 489 \\
\hline
\end{tabular}

58 patients signed an Informed Consent for the purposes of the study, divided into two groups:

- Group 1 comprised 28 patients (15 women and 13 men, mean age of $55 \pm 8$ years), who sought dental assistance in complete aesthetic rehabilitation of the masticatory apparatus using fixed bridge constructions. The patients consented to a pre-prosthetic periodontal and surgical preparation of the prosthetic field.

- Group 2 consisted of 30 patients (16 women and 14 men, mean age of $58 \pm 7$ years), who underwent prosthetic treatment without prior preparation of the prosthetics field.

All patients were selected based on the following inclusion criteria, suggested by the authors of the present paper: lack of common diseases, indications for prosthetic rehabilitation using fixed bridge constructions and presence of intraossal bone defects measuring more than $5 \mathrm{~mm}$ in depth. The study included medical history taking, extra- and intraoral examinations, panoramic imaging and documentation of the patient's periodontal status on a specially developed Dental Diagnostic Card. (Figure 1) 


\section{International Journal of Science and Research (IJSR) ISSN (Online): 2319-7064}

Index Copernicus Value (2015): 78.96 | Impact Factor (2015): 6.391

Dental Diagn ostic Card

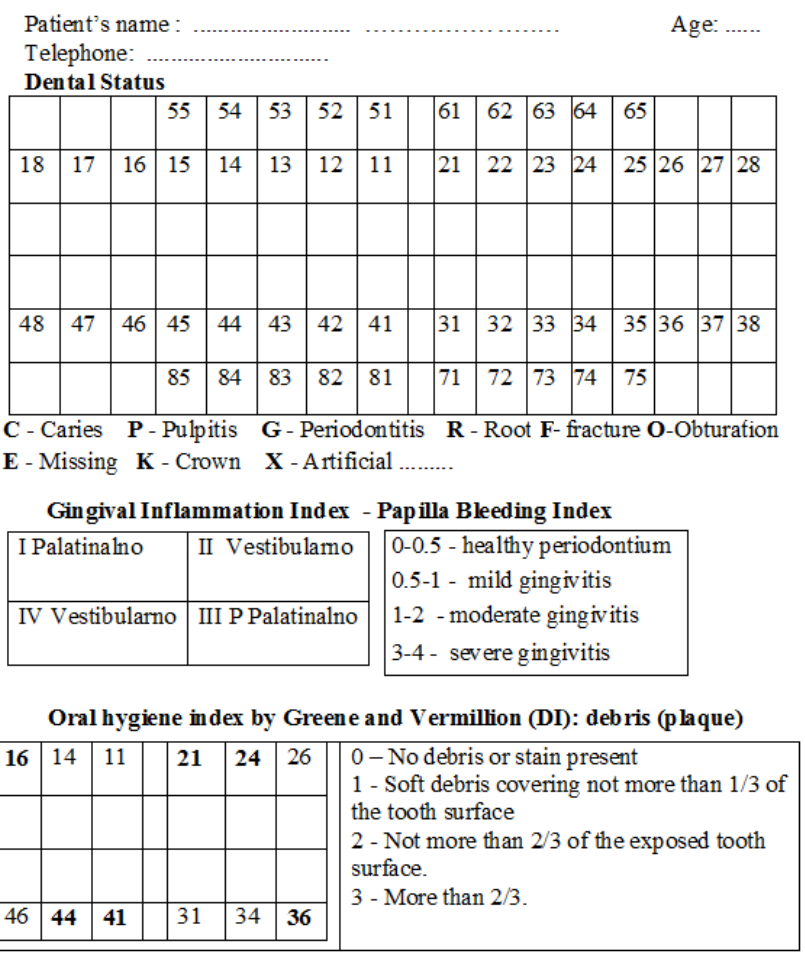

Figure 1: Dental Diagnostic Card

The pre-prosthetic preparation for Group 1 involved open flap curettage in the following sequence: dissection of the vestibular and oral mucoperiosteal flap, performing a crevicular vestibular and lingual incision as well as vertical incisions beyond the mucogingival line, which provided visibility and access to the base of the periodontal pockets. Calculus (tartar) and unhealthy granulation were removed from the bottom of the periodontal pockets, followed by smoothing and polishing of teeth root surfaces. Necessary tooth extractions were carried out. After gentle and careful hemostasis the flaps were adjusted and sutured with a 4-0 silk suture. An interim construction was fitted and a periodontal dressing was inserted for 7 days. (Figure 2)

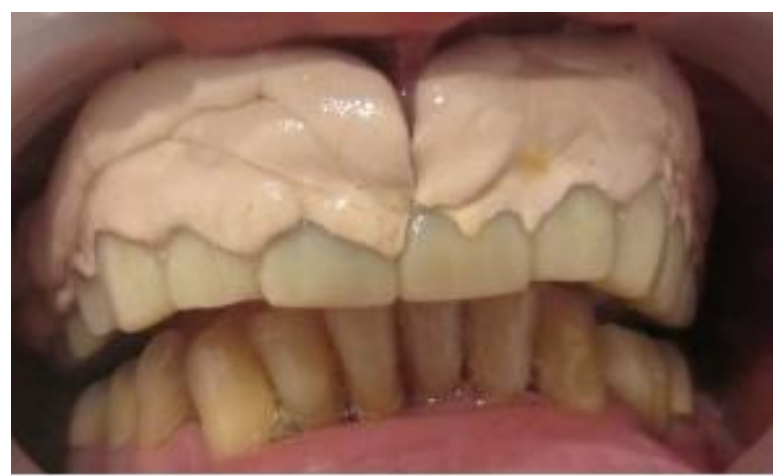

Figure 2: Patient M.Z. (62 years old) - an intraoral view after placing a periodontal dressing

Surgical dental crown lengthening (elongatio coronae dentis) proved necessary to perform, using gingivectomy or apically positioned flap surgery (APF). Depending on the size of the recession, gingival recessions affecting one or several teeth were treated by covering the exposed teeth roots or by microsurgical periodontal intervention using palate mucosa autotransplantation. Bone-grafting technique was applied with some of the patients in order to increase the bone level.
The size and type of bone-grafting granules were selected in view of each patient's individual characteristics.

Group 1 patients had their final fixed prosthesis fitted only upon full recovery of the periodontium after $5 \pm 1$ months. Group 2 patients had their prostheses mounted immediately after removal of the previous construction and following initial therapy. Key evaluation criteria included subjective complaints, such as cold sensitivity, spontaneous gum bleeding and bad breath, as well as the dental bridge life span, evaluated according to the three medico-biological criteria (preventive, functional and aesthetic criteria). The periodontal pocket depth around the abutment teeth was also assessed. All subjective complaints, the state of the prosthesis and the periodontium were checked and analyzed in 4 follow-up checks - after 1 week, 1 year, 2 years and 5 years. The data were analyzed using SPSS software for epidemiological and clinical research (Windows, V 16.0.0, Nov. 2007). The following statistical methods were applied: frequency and percentage distribution of data, graphical representation of data and Pearson's correlation coefficient, etc.

\section{Results and Discussion}

The data indicated that $82.14 \%$ of all participants had previous prosthetic treatment 5 or more years before that, which did not meet the basic medico-biological criteria. (Figure 3)

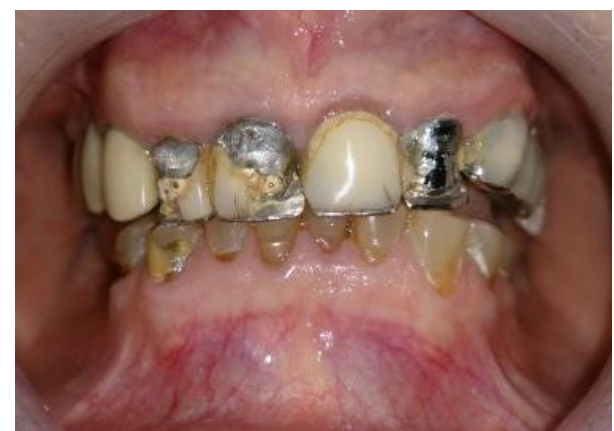

Figure 3: Patient M.B. (58 years old) - an intraoral view prior to treatment

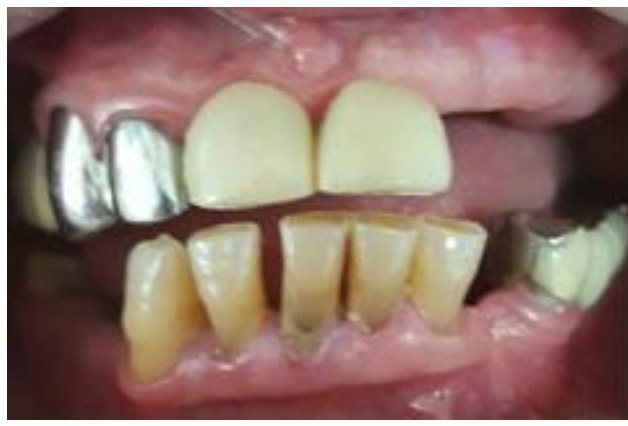

Figure 4: Patient K.K. (57 years old) - an intraoral view prior to treatment 


\section{International Journal of Science and Research (IJSR) \\ ISSN (Online): 2319-7064}

Index Copernicus Value (2015): 78.96 | Impact Factor (2015): 6.391

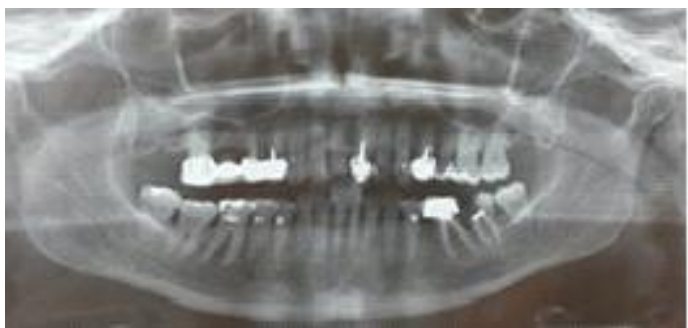

Figure 5: Patient E.M. (48 years old) - a panoramic image prior to treatment

$17.86 \%$ of participants did not have any prosthetic devices but had missing teeth or intraossal bone defects of varying depth. (Figures 6 and 7).

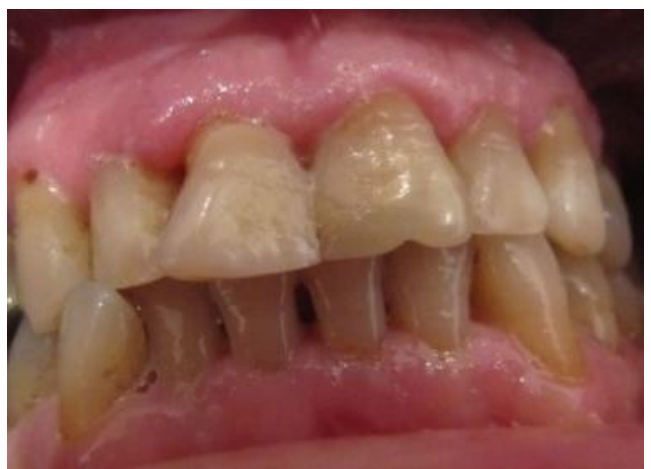

Figure 6: Patient L.P (48 years old) - an intraoral view prior to treatment

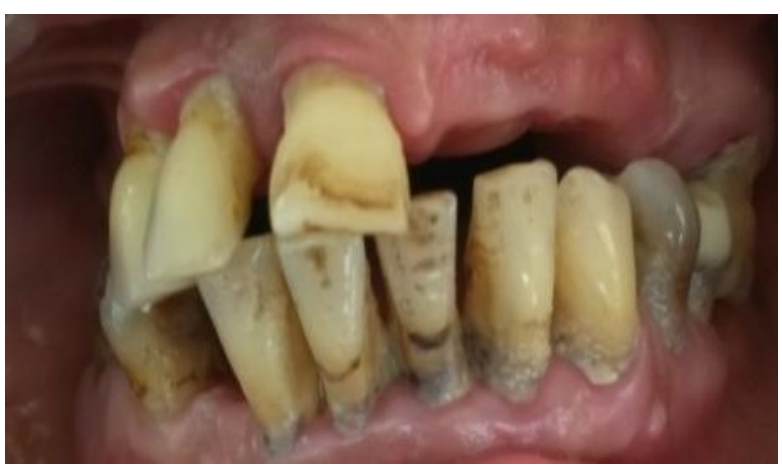

Figure 7: Patient S.S. (55 years old) - an intraoral view prior to treatment

At the initial examination $100 \%$ of patients had symptoms of bleeding gums, discomfort when chewing and increased sensitivity to cold.

The results demonstrated that $100 \%$ of Group 1 patients, who received prior periodontal and surgical treatment, showed initial periodontal pocket depth measuring $5 \pm 2$ $\mathrm{mm}$, later observed to be reduced to $2 \mathrm{~mm}$ as early as the first control examination before the prosthetic treatment. The same results were recorded 1 week after the prosthesis was fitted, and were retained in $75 \%$ of patients after 1 year. (Figure 8)

\section{Periodontal pocket depth (in mm)}

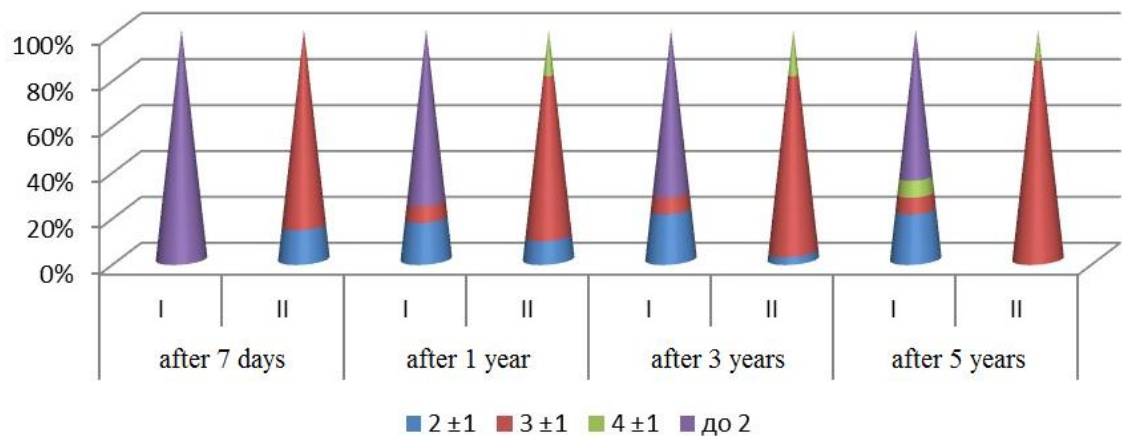

Figure 8: A graphical representation of the distribution of Group 1 participants according to the periodontal pocket depth (in $\mathrm{mm})$

The observations from the control examination showed that 1 week after the treatment, no patients in Group 2, who underwent pre-prosthetic preparation, had periodontal pocket depth of $2 \mathrm{~mm}$, and only $16.67 \%$ of participants in this group had pocket depth measuring $2 \pm 1 \mathrm{~mm}$. (Figure 8) The results observed at later examinations (after 3 years and 5 years) indicated that $71.43 \%$ of Group 1 patients did not have any change in the periodontal pocket depth, whereas in the majority of Group 2 patients $(76.67 \%)$ the pocket depth measured $3 \pm 1 \mathrm{~mm}$, which could potentially compromise the bridge construction. 5 years after the treatment all patients in Group 2 showed indications for new prosthetic rehabilitation, as opposed to only $7.14 \%$ in Group 1 . There was significant correlation between participants' affiliation to a particular group (Group 1 or Group 2) and the progression of the depth of the periodontal pockets $(\mathrm{P}=0.20)$.
The data obtained from the examinations of the prosthetic devices after 3 years revealed that according to the three basic medico-biological criteria there were no deviations from the norm in Group 1. After 5 years one patient showed discrepancy in the functional criterion, so did two patients in the preventive criterion, while four patients demonstrated discrepancy in the aesthetic criterion, which could be due to external factors (e.g. smoking, unsatisfactory oral hygiene, etc.). The observations showed that after 3 years in $50 \%$ of the patients in Group 2 there were discrepancies in the basic medico-biological criteria. Moreover, after 5 years the results were more alarming and there were indications for the need of new prosthetic rehabilitation. (Table 2) The linear correlation between the number of patients in Group 2 and the discrepancies in the preventive $(\mathrm{R}=0.792, \mathrm{P}<0.01)$, functional $(\mathrm{R}=0.742 \mathrm{P}<0.01)$ and aesthetic criteria $(\mathrm{R}=0.881$, 


\section{International Journal of Science and Research (IJSR) \\ ISSN (Online): 2319-7064}

Index Copernicus Value (2015): 78.96 | Impact Factor (2015): 6.391

$\mathrm{P}<0.01)$ was calculated using Pearson's correlation

coefficient.

Table 2: Percentage distribution in groups according to the three basic medico-biological criteria

\begin{tabular}{|c|c|c|c|c|c|c|c|c|}
\hline $\begin{array}{c}\text { Medico- } \\
\text { biological } \\
\text { Criteria/ } \\
\text { Assessment }\end{array}$ & $\begin{array}{c}\text { Group 1 } \\
\text { patients - } \\
\text { after 7 days }\end{array}$ & $\begin{array}{c}\text { Group 2 } \\
\text { patients - } \\
\text { after } 7 \text { days }\end{array}$ & $\begin{array}{c}\text { Group l } \\
\text { patients - } \\
\text { after l year }\end{array}$ & $\begin{array}{c}\text { Group 2 } \\
\text { patients - } \\
\text { after 1 year }\end{array}$ & $\begin{array}{c}\text { Group 1 } \\
\text { patients - } \\
\text { after } 3 \\
\text { years }\end{array}$ & $\begin{array}{c}\text { Group 2 } \\
\text { patients - } \\
\text { after } 3 \\
\text { years }\end{array}$ & $\begin{array}{c}\text { Group 1 } \\
\text { patients - } \\
\text { after } 5 \\
\text { years }\end{array}$ & $\begin{array}{l}\text { Group 2 } \\
\text { patients - } \\
\text { after } 5 \\
\text { years }\end{array}$ \\
\hline $\begin{array}{l}\text { Compliance } \\
\text { with the } \\
\text { Preventive } \\
\text { Criterion }\end{array}$ & $100 \%$ & $100 \%$ & $100 \%$ & $86.67 \%$ & $100 \%$ & $50 \%$ & $92.86 \%$ & $10 \%$ \\
\hline $\begin{array}{l}\text { Discrepancy in } \\
\text { the Preventive } \\
\text { Criterion }\end{array}$ & $0 \%$ & $0 \%$ & $0 \%$ & $13.33 \%$ & $0 \%$ & $50 \%$ & $7.14 \%$ & $90 \%$ \\
\hline $\begin{array}{l}\text { Compliance } \\
\text { with the } \\
\text { Functional } \\
\text { Criterion }\end{array}$ & $100 \%$ & $100 \%$ & $100 \%$ & $86.67 \%$ & $100 \%$ & $46.67 \%$ & $96.43 \%$ & $10 \%$ \\
\hline $\begin{array}{l}\text { Discrepancy in } \\
\text { the Functional } \\
\text { Criterion }\end{array}$ & $0 \%$ & $0 \%$ & $0 \%$ & $13.33 \%$ & $0 \%$ & $53.33 \%$ & $3.57 \%$ & $90 \%$ \\
\hline $\begin{array}{l}\text { Compliance } \\
\text { with the } \\
\text { Aesthetic } \\
\text { Criterion }\end{array}$ & $100 \%$ & $96.67 \%$ & $100 \%$ & $86.67 \%$ & $92.86 \%$ & $40 \%$ & $85.71 \%$ & $33.33 \%$ \\
\hline $\begin{array}{l}\text { Discrepancy in } \\
\text { the Aesthetic } \\
\text { Criterion }\end{array}$ & $0 \%$ & $3,33 \%$ & $0 \%$ & $13,33 \%$ & $7,14 \%$ & $60 \%$ & $14,29 \%$ & $66,67 \%$ \\
\hline
\end{tabular}

Discrepancy in any of the three basic medico-biological criteria is considered an indication for a new prosthetic treatment plan [8]. The permanence of prosthetic

constructions is often determined by the subjective perception of patients. (Table 3)

Table 3: Percentage distribution in groups according to subjective complaints

\begin{tabular}{|c|c|c|c|c|c|c|c|c|}
\hline $\begin{array}{c}\text { Subjective } \\
\text { complaints }\end{array}$ & $\begin{array}{c}\text { Group l } \\
\text { patients } \\
\text { after 7 } \\
\text { days }\end{array}$ & $\begin{array}{c}\text { Group 2 } \\
\text { patients } \\
\text {-after 7 } \\
\text { days }\end{array}$ & $\begin{array}{c}\text { Group 1 } \\
\text { patients } \\
\text {-after 1 } \\
\text { year }\end{array}$ & $\begin{array}{c}\text { Group 2 } \\
\text { patients } \\
\text { - after 1 } \\
\text { year }\end{array}$ & $\begin{array}{c}\text { Group 1 } \\
\text { patients } \\
- \text { after 3 } \\
\text { years }\end{array}$ & $\begin{array}{c}\text { Group 2 } \\
\text { patients } \\
\text {-after 3 } \\
\text { years }\end{array}$ & $\begin{array}{c}\text { Group 1 } \\
\text { patients } \\
\text { - after 5 } \\
\text { years }\end{array}$ & $\begin{array}{c}\text { Group 2 } \\
\text { patients } \\
\text { - after 5 } \\
\text { years }\end{array}$ \\
\hline $\begin{array}{c}\text { Sensitivity to } \\
\text { cold }\end{array}$ & $0 \%$ & $0 \%$ & $0 \%$ & $26.67 \%$ & $3.57 \%$ & $46.67 \%$ & $3.57 \%$ & $46.67 \%$ \\
\hline $\begin{array}{c}\text { No sensitivity } \\
\text { to cold }\end{array}$ & $100 \%$ & $100 \%$ & $100 \%$ & $73.33 \%$ & $96.43 \%$ & $53.33 \%$ & $96.43 \%$ & $53.33 \%$ \\
\hline $\begin{array}{c}\text { Spontaneous } \\
\text { gum bleeding }\end{array}$ & $0 \%$ & $3.33 \%$ & $0 \%$ & $40 \%$ & $0,00 \%$ & $53.33 \%$ & $3.57 \%$ & $60 \%$ \\
\hline $\begin{array}{c}\text { No } \\
\text { spontaneous } \\
\text { gum bleeding }\end{array}$ & $100 \%$ & $96.67 \%$ & $100 \%$ & $60 \%$ & $100 \%$ & $46.67 \%$ & $96.43 \%$ & $40 \%$ \\
\hline Bad breath & $0 \%$ & $0.00 \%$ & $0 \%$ & $33.33 \%$ & $0.00 \%$ & $50 \%$ & $3.57 \%$ & $60 \%$ \\
\hline No badbreath & $100 \%$ & $100 \%$ & $100 \%$ & $67.67 \%$ & $100 \%$ & $50 \%$ & $96.43 \%$ & $40 \%$ \\
\hline
\end{tabular}

The observations showed that Group 2 patients had subjective complaints as early as the first check-up, which intensified over time (after 3 and 5 years). Such complaints were not observed among Group 1 patients. The results only emphasized the difference between contaminated periodontal prosthetic field and a prosthetic field following periodontal treatment. (Figures 9 and 10)

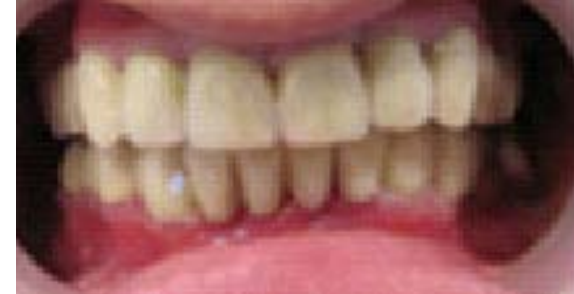

Figure 9: Patient M.Z. (62 years old) - an intraoral view 5 years after periodontal and prosthetic treatment 


\section{International Journal of Science and Research (IJSR) \\ ISSN (Online): 2319-7064}

Index Copernicus Value (2015): 78.96 | Impact Factor (2015): 6.391

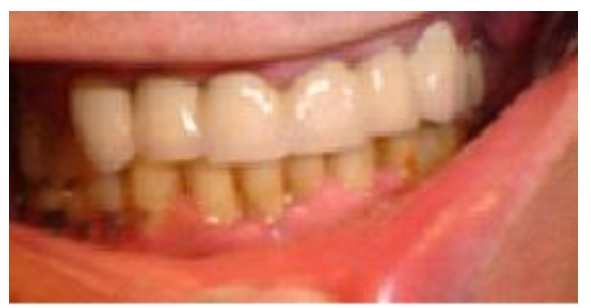

Figure 10: Patient S.S. (61 years old) - an intraoral view 5 years after prosthetic treatment

\section{Discussion}

The proper planning of prosthetic treatment with fixed dental constructions demands a thorough study and assessment of the anatomical characteristics and the clinical condition of both hard and soft tissues [9]. Biological and biophysical aspects play a huge role in the outcome of the prosthetic treatment $[6,10]$. Negligence of the state of the periodontal tissues, especially in the cases of upcoming prosthetic treatment, can dramatically affect the treatment success and its prognosis bona $[6,11]$. Discrepancy in any the basic medico-biological criteria is considered an indication for new prosthetic rehabilitation $[8,12]$.

\section{Conclusions}

The longevity of dental bridge prostheses is contingent on the state of the hard and soft tissue of the oral cavity. Preprosthetic periodontal treatment is essential for the purpose of long term functionality, lack of subjective complaints and good aesthetics of the treatment with fixed bridge constructions. Overlooking the need for pre-prosthetic periodontal preparation, where there are indications for it, can only lead to short-term benefits of the prosthetic treatment. Best long-term prognosis of the treatment with fixed prostheses can be achieved through an interdisciplinary approach.

\section{References}

[1] Liljenberg B, Gualini F, Berglundh T, Tonetti M, Lindhe J. Composition of plaque-associated lesions in the gingiva and the peri-implant mucosa in partially edentulous subjects. J Clin Periodontol. 1997; 24: 119123.

[2] Van Winkelhof AJ, Goene RJ, Benschop C, Folmer T. Early colonization of dental implants by putative periodontal pathogens in partially edentulous patients. Clin Oral Implants Res. 2000; 11:511-552

[3] Manev G, Popova C. Clinical diagnosis of inflammatory / destructive peri-implant diseases. Problems of dental medicine. 2013;1:39.

[4] Passariello C, Alessandra MP, Gigola VP. Microbiological and host factors are involved in promoting the periodontal failure of metaloceramic crowns. Clinical Oral Investigations . 2012; 16.(3): 987995.

[5] Ephros H, Klein R, Sallustio A. Preprosthetic Surgery. Oral Maxillofacial Surg Clin. 2015; 27: 459-472.

[6] Jansson L, Ehnevid H et al. Proximal restorations and periodontal status. J Clin Periodontol. 1994; 21:577-82
[7] Lindhe J, Nyman S, Lang NP. Treatment planning. In Lindhe J, Karring T, Lang N P (Ed). Clinical periodontology and implant dentistry. Oxford: Blackwell Munksgaard . 2003;4(19): 414-431.

[8] Filtchev A, Ralev R. Propedeutics of prostethic dental medicine. Sofia. 2010: 213

[9] Yung-Ting H, Nan-Chieh H, Hom-Lay W. Relationship between periodontics and prosthodontics: The two-way street. Journal of Prosthodontics and Implantology. 2015; 4: $4-11$

[10] Gašperšič R, Petelin M, Kopač I, Marion L, Skalerič U. The relationship between periodontal tissues and the gingival margin of prosthetic restorations. Zobozdrav Vestn. 2005; 60: 182- 192

[11]Uhač I, Kuiš D, Kavčič R, Lajnert V, Šoškić MŠ, Antonić $\mathrm{R}$ et al. Fixed prosthodontic restorations and periodontal health. Medicina Fluminensis. 2014; 50(3): $279-287$.

[12]Lang N. Periodontal consideration in prosthetic dentistry. Periodontology 2000. 1995; 9: 118-131.

\section{Author Profile}

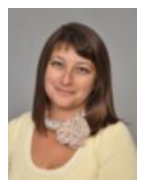

Dr. Desislava Konstantinova obtained her Master's degree in Dentistry in 1997 from the Medical University -Plovdiv. She has been working as an Assistant Professor at the Prosthetic Dentistry Department at the Medical University -Varna since 2008. She specialized in Prosthetic Dentistry in 2106 and was awarded a $\mathrm{PhD}$ degree in 2016.

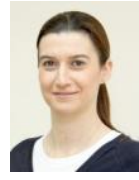

Dr. Anna Nenova-Nogalcheva obtained her Master's degree in Dentistry in 2006 from the Medical University - Plovdiv, Bulgaria. She has been working as an Assistant Professor at the Oral Maxillofacial Surgery Department at the Medical University -Varna since 2009. She specialized in Oral Surgery in 2012. 